\title{
Micronutrient status of female adolescent school dropouts
}

\author{
M de Lanerolle-Dias ${ }^{1}$, A de Silva ${ }^{2}$, P Lanerolle ${ }^{1}$, C Arambepola ${ }^{3}$, S Atukorala ${ }^{1}$ \\ (Index words: adolescent school dropouts)
}

\begin{abstract}
Objectives No data exists for nutritional status of female adolescent school dropouts despite one in seven adolescent girls in Sri Lanka being an early school leaver. The aim of this study was to assess the nutritional status of working and non-working female adolescent school dropouts.
\end{abstract}

Methods A cross-sectional design was used to recruit 613 female adolescent school dropouts, aged 15-19 years, in two districts of the Western Province of Sri Lanka. BMI was calculated by assessment of weight and height. Haemoglobin, serum ferritin, serum folic acid, vitamin B12, and serum zinc were measured.

Results When girls were grouped into age specific BMI categories, $32.8 \%$ of girls were underweight, while $6.1 \%$ were overweight. Prevalence of anaemia (haemoglobin $<120 \mathrm{~g} / \mathrm{l}$ ) in the study population was $17 \%$. Low iron status (serum ferritin $<20 \mu \mathrm{g} / \mathrm{l}$ ) was noted in $29.4 \%$ of girls, low serum folate in $28 \%$ (folic acid $<3 \mu \mathrm{g} / \mathrm{l}$ ) and zinc deficiency in $28.8 \%$ (zinc $<66 \mu \mathrm{g} / \mathrm{dl}$ ). Regression modeling indicated that dropping out of school early (at $<14$ years of age) was a significant risk factor for low serum ferritin $(p=0.001$, odds ratio $=2.1)$. Working adolescents were at greater risk of low micronutrient status: low serum ferritin $(p=0.009$; odds ratio $=1.8)$ serum folic acid $(p=0.006$; odds ratio $=1.9)$ and zinc deficiency $(p=0.001$; odds ratio $=2.1)$ than non-working adolescents.
Conclusions Dropping out of school early and being employed increases the risk of micronutrient deficiencies.

Ceylon Medical Journal 2012; 57: 74-78

\section{Introduction}

Despite adolescence being a critical period in a child's life, a high proportion of adolescent girls in the developing world are underweight, and suffer from micronutrient deficiencies, which affect growth and future pregnancy outcomes [1-3]. Micronutrient deficiencies of particular concern among adolescent girls in Asia are iron, folic acid, vitamin $A$ and zinc $[1,2,4,5]$. A significant gap in the literature exists regarding micronutrient deficiencies in adolescent school drop outs, despite a sizeable proportion of female adolescents dropping out of school in developing countries $[6,7]$.

In Sri Lanka, approximately one in seven adolescent girls is a school dropout and approximately $15 \%$ of girls aged 15 - 19 years, are employed [6]. Data from other developing countries such as India and Bangladesh report much earlier and higher rates of school dropout [7, 8]. Economic and social factors play a pivotal role in leaving school at an early age and such girls are more likely to be malnourished than their school going counterparts. Employment, often in poorly paid, unskilled jobs with long working hours and little benefits, contributes to poor nutritional status [9]. School dropouts also tend to enter marriage and employment at an earlier age than school

Departments of ${ }^{1}$ Biochemistry and Molecular Biology, ${ }^{2}$ Physiology, and ${ }^{3}$ Community Medicine, Faculty of Medicine, University of Colombo, Sri Lanka.

Correspondence: SA, e-mail: <sunethra@eol.Ik>. Received 17 November 2011 and revised version accepted 12 March 2012. Competing interests: none declared. 
girls, with pregnancy adversely affecting growth and nutritional status of the adolescent girl as well as her child, contributing to the inter-generational cycle of malnutrition $[3,10]$.

Our study aims to assess the nutritional status of female adolescent school dropouts in the Western Province of Sri Lanka.

\section{Methods}

This study reports the baseline nutritional status and employment data from a nutrition intervention study among adolescent school dropouts in the Western Province of Sri Lanka. The study was performed during the period of 2008 - 2009. Six hundred female adolescent school dropouts (15-19 years) were recruited. Considering a $20 \%$ difference between the intervention and control groups in relation to knowledge on micronutrients, an alpha error of $5 \%$, beta error of $10 \%$ (power of $90 \%$ ) with $1: 1$ ratio of the two groups, the minimum number of adolescents required in each group was calculated as 150 . Since the sample was stratified by urban and rural sectors, 300 adolescents from Colombo representing an urban district and another 300 from Kalutara representing a rural district were to be selected. In the absence of a sampling frame of out-of-school adolescent girls in each area, according to available baseline data on the proportion of out of school adolescents in each area, two Public Health Midwife (PHM) areas were selected from each of these two districts and all out-of-school adolescents within each were recruited to the study. However, the expected number of adolescents was not available in these areas during data collection and therefore, the sampling was extended to include the adolescents in four more PHM areas, which were located adjacent to each of the initially selected 4 PHM areas to achieve a sample size of 600 [11].

All participants were free of overt disease. Exclusion criteria were pregnancy, lactation or having a child below the age of 6 months. The participants provided written informed consent following protocols approved by the Ethics Review Committee of the Faculty of Medicine, University of Colombo, Sri Lanka.

Weight was measured to the nearest $0.1 \mathrm{~kg}$ with a calibrated electronic scale (Seca 813). Height was determined to the nearest $0.1 \mathrm{~cm}$ using a stadiometer (Seca 225 , telescopic height measurement) according to standard protocol. In order to avoid variability in results, all height and weight data were measured by one researcher using the same equipment and participants were attired in light indoor clothing. Body mass index (BMI) was calculated as weight $(\mathrm{kg}) /$ height $^{2}\left(\mathrm{~m}^{2}\right)$, and categorised into under weight, normal weight and overweight on the basis of age specific World Health Organisation classification of BMI for adolescent girls [12].

Non-fasting venous blood samples $(10 \mathrm{ml})$ were obtained from all participants under standardised conditions. Haemoglobin concentration was measured by the cyanmethaemoglobin method using reagent kits provided by Randox, UK. Serum ferritin was assessed by an immunoradiometric assay using the Ferritin IRMA Coata-Count test kit (DPC Inc USA) and measured using a Gamma Counter (Perkin Elmer, 1470). Serum folic acid/ vitamin B12 concentration was measured by radioisotopic assay (SimulTRAC-SNBMP Biomedicals Diagnostic Division, USA). Serum zinc concentrations were measured using a flame atomic absorption spectrometer (GBC, 932 plus). Inflammatory status was assessed using $\mathrm{C}$-reactive protein by latex agglutination (Humantex CRP complete test kit, Germany). Quality control was ensured by using control sera and an analytical variation $<5 \%$ for all assays.

Participants completed an interviewer administered questionnaire containing information on domains of occupation, education and schooling. Nutrition knowledge was assessed by a pre-tested self-administered questionnaire with true/false type responses.

The Statistical Package for the Social Sciences for Windows (v. 15.0, SPSS Inc., Chicago, IL, USA) was used in the data analysis. The level of significance was set at $p$ $<0.05$. As serum ferritin and zinc data did not show a normal distribution the data were normalised by $\log$ transformation prior to analysis. For assessment of nutrition knowledge, a composite score was calculated and expressed as a percentage.

Differences between non-working and working girls were assessed using the $\chi^{2}$ test for categorical variables and analysis of variance (ANOVA) for continuous variables. Anaemia was defined as haemoglobin $<120 \mathrm{~g} / \mathrm{L}$, low serum ferritin as ferritin $<20 \mu \mathrm{g} / \mathrm{L}$, low serum folic acid as folic acid $<3 \mu \mathrm{g} / \mathrm{L}$ low serum vitamin B12 as vitamin B12 $<150 \mathrm{pg} / \mathrm{ml}$ and zinc deficiency as serum zinc $<66 \mu \mathrm{g} / \mathrm{dl}$ [13-17]. Three separate binary logistic regression models were developed for the three dependent variables; low serum ferritin, low serum folic acid and zinc deficiency to examine the effects of different parameters (being employed, dropping out of school early ( $<14$ years), low income, low serum ferritin, low serum folic acid, zinc deficiency). Odds ratios and their $95 \%$ CI were calculated.

\section{Results}

Mean age of adolescent girls was $17.5 \pm 1.2$ years (15-19 years). Fifty eight percent of girls claimed that they dropped out of school between the ages of 14-16 years (Table 1). Reasons for dropping out included financial/ personal problems (47\%), cultural issues $(22.2 \%)$, to follow a vocational course or for employment (12.4\%) and failure at school examinations (18.4\%). Thirteen percent of study participants were married. All girls were from low income families (mean family income Rs. 13,666/ month). Approximately one third (32.5\%) were employed while others were not. The majority of employed girls $(86.7 \%)$ were unskilled workers mostly in factories, $7.1 \%$ were 
skilled workers and $6.1 \%$ were self-employed. The mean total family income/month was significantly $(p=0.022)$ higher among working girls (Rs. 15,518) than non-working girls (Rs. 12,908). Monthly income of the girls ranged from Rs. 200 - 13,000.

Non-working girls showed a trend $(p=0.06)$ towards a higher mean knowledge score on nutrition than working girls (working girls: $49.7 \%, \mathrm{SD}=19.6 \%$ vs non-working girls: $53 \%, \mathrm{SD}=20.1 \%$ ).

Of the total population, one third of the girls $(32.8 \%$, $\mathrm{n}=199)$ were underweight while $6.1 \%(\mathrm{n}=37)$ were overweight. The proportion of girls who were underweight was similar among non-working and working girls. In contrast, there was a higher proportion of overweight girls among non-working girls than working girls (Table 2). Of the total population, $17 \%(n=103)$ were anaemic, $29.4 \%$ $(n=172)$ had low serum ferritin concentrations, $28 \%(n=59)$ had low serum folic acid concentrations, and $28.8 \%(\mathrm{n}=$ 127) were deficient in zinc (Table 2). Although the prevalence of anaemia was similar among working and non working girls, a significantly higher percentage of working girls had low serum ferritin concentrations $(p=0.037)$, low serum folic acid concentrations $(p=0.006)$ and zinc deficiency $(p<0.001)$.

Results of binary logistic regression modeling using low serum ferritin, low serum folic acid or zinc deficiency as dependent variables indicate that working adolescents are more vulnerable to micronutrient deficiency than nonworking girls (Table 3). Dropping out of school at a younger age $(<14$ years) resulted in greater than twice the risk $(p=0.01$, odds ratio $=2.1)$ of having a low iron status than girls who dropped out of school at an older age ( $>14$ years). Working adolescent girls were at nearly twice the risk ( $p=0.009$, odds ratio $=1.8$ ) of having low serum ferritin and low serum folic acid concentrations $(p=0.006$, odds ratio $=1.9)$ and greater than twice the risk $(p<0.001$, odds ratio $=2.1$ ) of having zinc deficiency when compared with non-working adolescents (Table 3 ).

Table 1. Socio-demographic characteristics

\begin{tabular}{|c|c|c|c|}
\hline & $\begin{array}{l}\text { Total population } \\
\qquad(n=603) \\
n(\%)\end{array}$ & $\begin{array}{c}\text { Non-working } \\
(n=407) \\
n(\%)\end{array}$ & $\begin{array}{l}\text { Working } \\
(n=196) \\
n(\%)\end{array}$ \\
\hline Age years $($ mean $\pm \mathrm{SD})$ & $17.35 \pm 2.1$ & $17.19 \pm 2.4$ & $17.67 \pm 1.021$ \\
\hline$<16$ years & $43(7.1)$ & $39(9.6)$ & $4(2)$ \\
\hline $16-19$ years & $560(92.9)$ & $368(90.4)$ & $192(97.9)$ \\
\hline \multicolumn{4}{|l|}{ Age of dropping out of school ${ }^{3}$} \\
\hline No schooling & $3(0.5)$ & $3(0.8)$ & - \\
\hline 6 - 10 years (primary) & $8(1.4)$ & $8(2)$ & - \\
\hline 11 - 13 years (middle school) & $58(9.9)$ & $45(11.5)$ & $13(6.6)$ \\
\hline 14 - 16 years (upper school) & $343(58.4)$ & $244(62.4)$ & $99(50.5)$ \\
\hline 17 - 19 years (upper school) & $175(29.8)$ & $91(52)$ & $84(42.9)$ \\
\hline \multicolumn{4}{|l|}{ Marital status $^{4}$} \\
\hline Married & $80(13.4)$ & $63(15.6)$ & $17(8.9)$ \\
\hline Unmarried & $517(86.6)$ & $342(84.4)$ & $175(91.1)$ \\
\hline Monthly family income (Rs.) & 13,666 & 12,908 & 15,5182 \\
\hline$<9,000$ & $302(50.1)$ & $211(52)$ & $91(46.4)$ \\
\hline $9,000-19,000$ & $191(31.7)$ & $131(32.1)$ & $60(30.6)$ \\
\hline$>19,001$ & $110(18.2)$ & $65(15.9)$ & $45(23)$ \\
\hline
\end{tabular}


Table 2. General nutritional status, anaemia and micronutrient status and of working and non-working adolescent school dropouts

\begin{tabular}{lcc}
\hline & $\begin{array}{c}\text { Non-working } \\
n(\%) \\
(n=407)\end{array}$ & $\begin{array}{c}\text { Working } \\
n(\%) \\
(n=196)\end{array}$ \\
\hline General nutritional status & & \\
$\quad$ under weight & $138(33.9)$ & $61(31.1)$ \\
normal weight & $235(57.7)$ & $3(1.5)$ \\
overweight & $34(8.4)$ & $38(19.8)$ \\
Anaemia and micronutrient status & & $65(35.0)^{1}$ \\
anaemic: (haemoglobin $<120 \mathrm{~g} / \mathrm{L})$ & $64(16.0)$ & $65(35.9)^{2}$ \\
low serum ferritin $($ ferritin $<20 ? \mathrm{~g} / \mathrm{L})$ & $106(27.0)$ & $3(1.7)$ \\
low serum folic acid $($ folate $<3$ ?g/L) & $94(24.7)$ & $53(42.1)^{3}$ \\
low serum vitamin $\mathrm{B} 12(\mathrm{~B} 12<150 \mathrm{pg} / \mathrm{ml})$ & $7(1.8)$ & \\
zinc deficiency $($ serum $\mathrm{Zn}<66 \mu \mathrm{g} / \mathrm{dl})$ & $73(23.4)$ &
\end{tabular}

Table 3. Logistic regression analysis to identify the risk factors for low serum ferritin, low serum folic acid or zinc deficiency

\begin{tabular}{|c|c|c|c|c|c|c|}
\hline \multirow[t]{2}{*}{ Dependent variable } & \multicolumn{6}{|c|}{$\begin{array}{c}\text { Independent variables } \\
\text { odds ratio }(95 \% \text { CI) }\end{array}$} \\
\hline & Employed & $\begin{array}{l}\text { Dropping out } \\
\text { of school early } \\
\text { (<14 years) }\end{array}$ & $\begin{array}{c}\text { Low } \\
\text { income }\end{array}$ & $\begin{array}{c}\text { Zinc } \\
\text { deficiency }\end{array}$ & $\begin{array}{l}\text { Low } \\
\text { folic acid }\end{array}$ & $\begin{array}{c}\text { Low } \\
\text { ferritin }\end{array}$ \\
\hline Low ferritin & $\begin{array}{c}1.8 \\
(1.2,2.9)^{1}\end{array}$ & $\begin{array}{c}2.1 \\
(1.2,3.7)^{2}\end{array}$ & $\begin{array}{c}1.2 \\
(0.8,1.8)\end{array}$ & $\begin{array}{c}1.4 \\
(0.8,2.1)\end{array}$ & $\begin{array}{c}1.1 \\
(0.7,1.8)\end{array}$ & - \\
\hline Low folic acid & $\begin{array}{c}1.9 \\
(1.2,3.06)^{3}\end{array}$ & $\begin{array}{c}1.5 \\
(0.8,2.8)\end{array}$ & - & - & - & $\begin{array}{c}1.2 \\
(0.7,1.8)\end{array}$ \\
\hline Zinc deficiency & $\begin{array}{c}2.1 \\
(1.3,3.4)^{4}\end{array}$ & $\begin{array}{c}1.0 \\
(0.56,1.9)\end{array}$ & & - & - & $\begin{array}{c}1.37 \\
(0.8,2.1)\end{array}$ \\
\hline
\end{tabular}

\footnotetext{
${ }^{1,2}$ Significant risk factor for low serum ferritin concentrations $\left({ }^{1} p=0.009,{ }^{2} p=0.01\right)$

${ }^{3}$ Significant risk factor for low serum folic acid concentrations $(p=0.006)$

4 Significant risk factor for zinc deficiency $(p<0.001)$
}

\section{Discussion}

Our results indicate that school dropouts are nutritionally vulnerable with both macro and micronutrient status being suboptimal. One third of the study population was underweight with $6 \%$ of girls being overweight. Micronutrient deficiency was common, with the prevalence of anaemia being $17 \%, 28 \%$ having low folate status, $29.4 \%$ with low iron status and $28.8 \%$ being zinc deficient. Further, the risk of poor nutritional status was greater among girls who dropped out earlier $(<14$ years of age).

Regional data on school dropouts have not assessed nutritional status [7, 8]. The lack of data globally of nutritional status among school dropouts does not allow 
a comparative discussion of our findings. Our data suggest that employment poses an additional burden in nutritional terms. The risk of micronutrient deficiency was greater among working girls compared with non-working girls, even though nutrition related knowledge was not greatly different between working and non-working girls. Despite a significantly higher family income, employed girls had a lower micronutrient status, showing that the additional small income generated by these girls does not have a positive effect on their nutritional status. Work for pay is not the only type of labour that interferes with nutrition of these girls. Girls who stayed at home were also nutritionally vulnerable, with a third of the girls being underweight, and having low serum ferritin, low serum folic acid concentrations and zinc deficiency.

To our knowledge, there are no intervention programmes at present targeting adolescent school dropouts and our findings highlight the need. Since the longer children are in school, the more likely it is that they will gather nutrition knowledge and practice good nutrition, school programmes need to address issues of dropping out of school while these girls are still schooling to prevent early dropout as well as empower girls with knowledge and skills earlier in their school life [18]. The many facets that contribute to nutritional vulnerability in the school dropout have to be addressed through multiple strategies. Addressing the nutrition needs of this vulnerable group of adolescents could be an important step towards breaking the cycle of poverty, intergenerational malnutrition and chronic disease.

\section{Acknowledgements}

The authors thank Thisira Andrahennadhi, Department of Biochemistry and Molecular Biology, Faculty of Medicine and Sisira de Silva, Department of Chemistry, Faculty of Science, University of Colombo for technical assistance. This project was funded in part by International Atomic Energy Agency (IAEA) Vienna, Austria, Grant Number SRL6/030 and by the Nutrition Coordination Division Sri Lanka Grant Number 2.1.b.G/vi.

\section{References}

1. Ahmed F, Khan MR, Islam M, Kabir I, Fuchs GJ. Anaemia and iron deficiency among adolescent schoolgirls in periurban Bangladesh. European Journal of Clinical Nutrition 2000; 54: 678-83.

2. Bently ME, Griffiths PL. The burden of anaemia among women in India. European Journal of Clinical Nutrition 2003; 57: $52-60$

3. Goonewardene IMR, Waduge RPKD. Adverse effects of teenage pregnancy. Ceylon Medical Journal 2005; 50: 116-20.

4. Atukorala S, Lanerolle P. Serum folic acid levels of adolescent schoolgirls in a rural area. Ceylon Medical Journal 1998; 43: 238-9.
5. Thoradeniya $\mathrm{T}$, Wickremasinghe $\mathrm{R}$, Ramanayake R, Atukorala S. Low folic acid status and its association with anaemia in urban adolescent girls and women of childbearing age in Sri Lanka. British Journal of Nutrition 2006; 95: 511-6.

6. Sri Lanka Labour Force Survey - Annual Report 2009; Summary Statistics on Labour Force Characteristics. Department of Census and Statistics, Ministry of Finance and Planning, Sri Lanka.

7. Reddy AN, Sinha S. School dropouts or pushouts. overcoming barriers for the right to education. Consortium for Research on Educational Access, Transitions and Equity 2010; 40: 1-33.

8. Sabates R, Hossain A, Lewin KM. School drop out in Bangladesh: new insights from longitudinal evidence. Consortium for Research on Educational Access, Transitions and Equity 2010; 49: 1-30.

9. Roggero P, Mangiaterra V, Bustreo F, Rosati F. The health impact of child labor in developing countries: evidence from cross-country data. American Journal of Public Health 2007; 97: 271-5.

10. Konje JC, Palmer A, Watson A, Hay DM, Imrie A. Early teenage pregnancies in Hull. British Journal of Obstetrics and Gynaecology 1992; 99: 969-73.

11. Fleiss JL. Statistical Methods for Rates and Proportions. 2nd edition, John Wiley \& Sons, 1981: 44-45.

12. de Onis M, Onyango AW, Borghi E, Siyam A, Nishida C, Siekmann J. Development of a WHO growth reference for school-aged children and adolescents. Bulletin of the World Health Organization 2007; 85: 660-7.

13. WHO/UNICEF/UNU, eds. Iron Deficiency Anaemia Assessment, Prevention, and Control: A Guide For Programme Managers. Geneva, Switzerland: World Health Organization, 2001 (WHO/NHD/01.3).

14. van Stuijvenberg ME, Kvalsvig JD, Faber M, Kruger M, Kenoyer DG, Benadé AJS. Effect of iron-, iodine-, and bcarotene-fortified biscuits on the micronutrient status of primary school children: a randomized controlled trial. American Journal of Clinical Nutrition 1999; 69: 497-503.

15. Herbert V. Folic acid. In: Olson JA and Shike M, editors. Modern Nutrition in Health and Disease. 9th ed. USA: William \& Wilkins, 1999; 1: 433-46.

16. Lindenbaum J, Healton EB, Marcell PD, Stabler SP, Allen RH. Neuropsychiatric disorders casued by cobalamin deficiency in the absence of anaemia or macrocytosis. New England Journal of Medicine 1988; 318: 1720-28.

17. Hotz $\mathrm{C}$ and Brown KH eds. Assessment of the risk of zinc deficiency. In: Assessment of the risk of zinc deficiency in populations and options for its control. International Zinc Nutrition Consultative Group Technical Document \# 1. Food and Nutrition Bulletin 2004; 25 (Supp): S130-S162

18. Heady C. The effect of child labor on learning achievement. World Development 2003; 31: 385-98. 